\title{
Microenvironmental Regulators of Tissue Structure and Function Also Regulate Tumor Induction and Progression: The Role of Extracellular Matrix and Its Degrading Enzymes
}

\author{
M.J. Bissell, P.A. KenNy, AND D.C. RADiskY* \\ Cancer Biology Department, Life Sciences Division, Lawrence Berkeley National Laboratory, \\ University of California, Berkeley, California 94720
}

\begin{abstract}
It is now widely accepted that elements of the cellular and tissue microenvironment are crucial regulators of cell behavior in culture and homeostasis in vivo, and that many of the same factors influence the course of tumor progression. Less well established is the extent to which extracellular factors actually cause cancer, and the circumstances under which this may occur. Using physiologically relevant three-dimensional culture assays and transgenic animals, we have explored how the environmental and architectural context of cells, tissues, and organs controls mammary-specific gene expression, growth regulation, apoptosis, and drug resistance and have found that loss of tissue structure is a prerequisite for cancer progression. Here we summarize this evidence and highlight two of our recent studies. Using mouse mammary epithelial cells, we show that exposure to matrix metalloproteinase-3 (MMP-3) stimulates production of reactive oxygen species (ROS) that destabilize the genome and induce epithelial-mesenchymal transition, causing malignant transformation. Using a human breast cancer progression series, we find that ADAM-dependent growth factor shedding plays a crucial role in acquisition of the malignant phenotype. These findings illustrate how normal tissue structure controls the response to extracellular signals so as to preserve tissue specificity and growth status.
\end{abstract}

\section{INTRODUCTION AND HISTORICAL BACKGROUND}

Key questions in cell and tumor biology include how tissues and organs maintain homeostasis, and how cells within organs lose or overcome these controls in cancer. Developmental pathways may be thought of as a series of extremely rapid short-term events in which each new step depends on the previous state with the final outcome at birth being the organism itself. In mice and humans, these developmental events occur in a mere 21 days or 9 months, respectively, but the stability of the differentiated state and the homeostasis of the organism will last 40-110 times longer. Defining how this extraordinary balance is maintained is key to understanding how the stability is lost in the development of malignancy and aging. The importance of "tissue interaction" to define cellular function was recognized as early as the turn of the previous century (Peebles 1911). However, despite the fact that Alexis Carrel published his landmark articles on maintaining cells and tissues outside the animal around this time (Carrel 1908, 1911), intensive investigations of the factors controlling the stability of the differentiated state did not begin in earnest until the early 1970s, with the recognition that the microenvironment has a profound effect on how cells behave in culture (for a review of the early literature, see Bissell 1981). These early studies concentrated on a few molecules gained or lost in culture-the process we loosely define as differentiation.

Present address: Mayo Clinic Cancer Center, Griffin Cancer Research Building, 4500 San Pablo Road, Jacksonville, Florida 32224
The role played by the microenvironment in providing a "congenial soil" for tumor growth was identified at the end of the 19th century (Paget 1889), but the discovery of tumor viruses, oncogenes, and tumor suppressors in the 20th century overshadowed these earlier studies as most workers pursued cell-autonomous mechanisms for cancer cell initiation, progression, and metastasis. However, much important work was done in developmental biology, where it was recognized that the epithelial and stromal tissue components engage in a dynamic cross talk during development and play a crucial role in tissue morphogenesis and differentiation. The groundbreaking transplantation experiments in salamanders of Spemann and Mangold demonstrated the power of certain regions of tissues to interact with, and modulate, the differentiation of adjacent structures (Spemann 1918; Spemann and Mangold 1924). Similarly, mammalian tissue coculture experiments defined some of the reciprocal interactions between epithelial and mesenchymal tissues necessary for the induction of the differentiated state in several organs (Grobstein 1964 and references therein; Sakakura et al. 1976). The identities and roles of many of the key signaling molecules have now been elucidated in several organ systems, including the lung (Cardoso 2001), kidney (Yu et al. 2004), gut (Roberts 2000), and mammary gland (Parmar and Cunha 2004).

With the new molecular and genetic tools available to us at the turn of this new century, we are beginning to understand more fully the complexity of the programs and forces that maintain the unity of form and function in normal organs, and the validity of the instability/plasticity of the differentiated state (Bissell 1981; Blau and Baltimore 1991). These tools and techniques have enabled us to 
show that frank cancer cells can be "reverted" to a phenotypically normal state, and how normal tissues may develop epithelial tumors by alterations in the microenvironment and the stroma.

\section{THE IMPORTANCE OF CELLULAR AND TISSUE CONTEXT}

That changes in the stromal component play a role in tumor development has long been obvious to surgeons and pathologists. Resection and analysis of tumors show that they are often tough and fibrotic as a result of deposition of collagens and other extracellular matrix (ECM) molecules by stroma. Dvorak noted extensive parallels between tumor-associated stroma and the stroma induced by wound healing, leading him to suggest that "A tumor is a wound that does not heal" (Dvorak 1986). This is referred to as "reactive" stroma, and the mechanisms by which malignant cells induce these changes in nonmalignant fibroblasts are now beginning to be understood (Ronnov-Jessen et al. 1996). The advent of effective means to separate epithelial and stromal cells and recombine them in culture or in vivo provided a tool to dissect the contributions of these lineages to the malignant state. It is becoming apparent that the tumor stroma is not merely responsive to the developing tumor, but in fact is an active participant in the tumorigenic process. As with normal development, the interaction between epithelium and stroma in tumor initiation and progression is not a monolog but a dialog, or a highly organized group discussion!

Evidence for a cancer-relevant dialog between epithelium and stroma began to accumulate in the 1970s. DeCosse and coworkers showed that a mammary tumor could be induced to differentiate by coculture (across a filter) with embryonic mammary mesenchyme (DeCosse et al. 1973). A comprehensive series of xenograft experiments by Leland Chung demonstrated that co-injection of either nontransformed or transformed fibroblasts greatly enhanced the tumorigenicity in athymic mice of a series of human cancer cell lines from different tissues (Camps et al. 1990). Similarly, Cunha and his collaborators showed that fibroblasts isolated from the reactive tumor stroma had the capacity to transform otherwise nonmalignant immortal prostatic epithelial cells in this assay (Olumi et al. 1999; Cunha et al. 2004). Conversely, prostate cancer cells could be induced to differentiate when co-engrafted with several different types of mesenchyme (Hayashi et al. 1990).

Although these experiments clearly demonstrated that dialog between epithelium and stroma plays a critical role in neoplasia, the language of communication was still a mystery, including the identity of the paracrine signaling molecules and the cell types which produce these signals. Expression analysis of the different cell populations that comprise the normal and malignant breast is now providing insight into the cells that generate and respond to these signals (Allinen et al. 2004), and it is clear that leukocytes, particularly macrophages, play a prominent role (Bingle et al. 2002). Tumor-infiltrating leukocytes have long been associated with cancer (Virchow 1863) and were long thought to be a hallmark of the immune response to the tumor. It is now appreciated that these tumor-associated macrophages (TAMs) are actually recruited to the tumor as a result of tumor cell expression of chemotactic cytokines. Once recruited, TAMs provide a rich supply of cytokines, proteases, and growth factors that stimulate tumor growth and promote neo-angiogenesis (Pollard 2004). Yet more signaling proteins, such as MSF produced by fibroblasts in the tumor stroma (Schor et al. 2003), exert potent stimulatory effects on malignant cells.

\section{ORGAN ARCHITECTURE AND CONTEXT AS OVERRIDING TUMOR SUPPRESSORS}

The maintenance of tissue architecture and organization, as well as tissue polarity and differentiation, is dependent on continued dialog between the cells and their microenvironment. Loss of organization is among the earliest histological hallmarks of malignant progression. Although the role of activated oncogenes and inactivated tumor suppressors in cancer development is clear, studies of large autopsy series reveal that the majority of people who die from causes other than cancer have small neoplastic growths throughout their bodies (Harach et al. 1985; Nielsen et al. 1987; Montie et al. 1989). It is thus also clear that loss of single tumor suppressors, although necessary, is not sufficient to induce tumors, since inherited mutations such as BRCA1, BRCA2, and APC lead to organ-specific tumors, rather than a general increase in all cancers. What is it that constrains these neoplastic growths and keeps the other tissues intact in the absence of the suppressor genes? Early evidence from a number of laboratories, including ours, has indicated that the tissue microenvironment including its "organ-specific form" can exert a potent tumor suppressive effect, even when cells were infected with potent oncogenes.

In a remarkable experiment performed three decades ago, Beatrice Mintz demonstrated that embryonal carcinoma cells (which form malignant tumors upon injection in adult mice), could contribute to cancer-free normal tissues when injected into blastocysts (Mintz and Illmensee 1975). These data are a striking exposition of the power of the tissue context to modify the malignant potential of cancer cells. Similar and complementary experiments were recently reported by Chin and Jaenisch and coworkers (Hochedlinger et al. 2004). In these, nuclei from rastransformed melanoma cells were shown to contribute to adult tissues in chimeric mice, although in this case the mice did develop tumors eventually.

Our laboratory focused on Rous sarcoma virus (RSV). This virus, which encodes the potent transforming oncogene, v-src, causes sarcoma formation in adult birds and mass transformation of cells in culture (for review, see Martin 2004). We found that infection of embryos in ovo with virally encoded Src did not preclude normal embryonic development even though the oncogene was expressed (Dolberg and Bissell 1984), and active (Howlett et al. 1988; Stoker et al. 1990a). Nevertheless, cells iso- 
lated from these embryos became transformed en masse when dissociated and placed on tissue culture plastic, demonstrating the importance of context to modify the phenotype of an oncogenically transformed cell. Furthermore, whereas it was widely accepted that viral infection was necessary and sufficient for induction of tumors, we found that RSV-induced tumors would remain local despite circulating virus. We subsequently showed that wounding of infected chickens was in fact necessary and that wounding the chicken at a site different from the original RSV injection was sufficient to induce tumors at the site of wounding. Finally, we showed that TGF- $\beta 1$ was a key mediator in this process (Sieweke et al. 1990), one of the early demonstrations of the dual role of TGF- $\beta$ in normal and malignant behavior. These data demonstrated that oncogene expression was compatible with normal nonneoplastic tissue morphogenesis in the embryo, and that the tumorigenic phenotype could be revealed following microenvironmental perturbations such as those induced by cellular cultivation on tissue culture plastic or wounding in the adult chicken.

Several differences exist in wound healing between the embryo and the adult (Ferguson and O'Kane 2004). Embryonic wounds often heal without scar formation, perhaps because at this developmental stage the skin is actively growing and is rich in morphogenetic growth factors. In adults, the skin is more refractory to healing, which results in scar formation. In contrast to adults, embryonic wounds typically have little inflammatory cell infiltration. The isoforms of TGF- $\beta$ present at the wound site also differ between embryo and adult. TGF- $\beta 3$ is the predominant isoform in embryonic wounds, whereas TGF- $\beta 1$ and TGF- $\beta 2$ are present in adults. Introduction of TGF- $\beta 3$ into adult wounds promotes scar-free healing (Shah et al. 1995), whereas genetic ablation of TGF- $\beta 3$ prevents embryonic scar-free healing (Ferguson and O'Kane 2004). These data provide insight into our observations that introduction of RSV by injection in chick embryos did not yield tumors, whereas subsequent wounding of the adult birds, at distant sites, did.

There is much literature (going back to the 19th century) describing the changes that occur in the wounding environment - which included disruption and remodeling of basement membrane (BM), activation of the stroma, immune cell infiltration and degranulation, and, ultimately, scar formation. These events can also provide an oncogenic stimulus to cells with genetic alterations (for a review of the early literature, see Sieweke and Bissell [1994]; for a more recent review see Robinson and Coussens [2005]). But what are the molecular effectors of stability and disruption? One of the problems of trying to define the role of specific components of ECM, BM, or adhesion molecules in development of malignancy is that their very absence is often lethal. Nevertheless, there is increasing evidence that attenuated function of these molecules is indeed instrumental in tumor induction, poor prognosis, and increased progression (Table 1; see the final section of this paper). Dissecting more complex levels of molecular interaction will clearly require robust and more sophisticated models.

\section{THE MAMMARY GLAND AS AN EXPERIMENTAL ORGANISM}

To understand the signaling pathways involved in the maintenance of the differentiated state, and to gain insight into the steps that cause and promote malignancy, our laboratory has concentrated for the past 25 years exclusively on one system, that of the mammary gland of mice and humans. We postulated (Bissell et al. 1982), and then demonstrated (for reviews, see Stoker et al. 1990b; Roskelley et al. 1995; Bissell et al. 1999, 2003; Schmeichel and Bissell 2003), that components of the ECM provide critical physical and biochemical cues to epithelial cells, and cooperate with hormones and growth factors to signal to the nucleus and chromatin to maintain mammary-specific gene expression. In parallel, we have been concerned with the loss of tissue organization and polarity, which is among the earliest histological manifestations of an incipient tumor.

The availability of genetic engineering techniques in mice and our ability to culture cells in three-dimensional (3D) gels as a surrogate for normal tissues (Michalopoulos and Pitot 1975; Emerman and Pitelka 1977; Barcellos-Hoff et al. 1989; Petersen et al. 1992) have now made it possible to study the molecular mechanisms involved in how changes in the microenvironment translate into changes in gene expression. One of the first demonstrations that changes in culture substrata and cell shape led to changes in de novo gene expression was performed with murine mammary cells and synthesis and secretion of radiolabeled milk proteins (Lee et al. 1984, 1985). Subsequent studies have demonstrated that expression of tissue-specific genes such as milk proteins are not coordinate but that there is a hierarchy of expression directly related to the nature of the ECM molecules, cell-cell interactions, and complexity of the tissue-specific architecture achieved in culture (Fig. 1A) (for review, see Lin and Bissell 1993). Although not all the transcripts have been interrogated in the case of the mouse mammary cells, it is clear that a number of signaling pathways are shut off and others are turned on; i.e., there is change in the program of tissue-specific gene expression when the cells receive the ECM and cell-shape signals. The postulate that these changes are directly related to cell-ECM interactions was demonstrated by studies that showed $\beta$-casein expression is disrupted as a function either of inhibition of specific integrins (Streuli et al. 1991; Muschler et al. 1999) or use of specific inhibitory peptides to chains of laminin-1 (Streuli et al. 1995).

Using $\beta$-casein as the prototype, we discovered that there is an ECM-response element in the promoter of the $\beta$-casein gene (Fig. 1B, C) that responds to laminin-1 and prolactin. The response was quite dramatic and involved recruitment and activation of transcription factors Stat5 and C/EBP $\beta$, and widespread alterations in chromatin structure (Schmidhauser et al. 1992; Myers et al. 1998; R. Xu et al., in prep.). We later showed that other genes also contain ECM or substrata-response elements, and in some cases, such as that of the TGF- $\beta 1$ gene, the response to ECM was suppression of expression rather than induction (Streuli et al. 1993). 


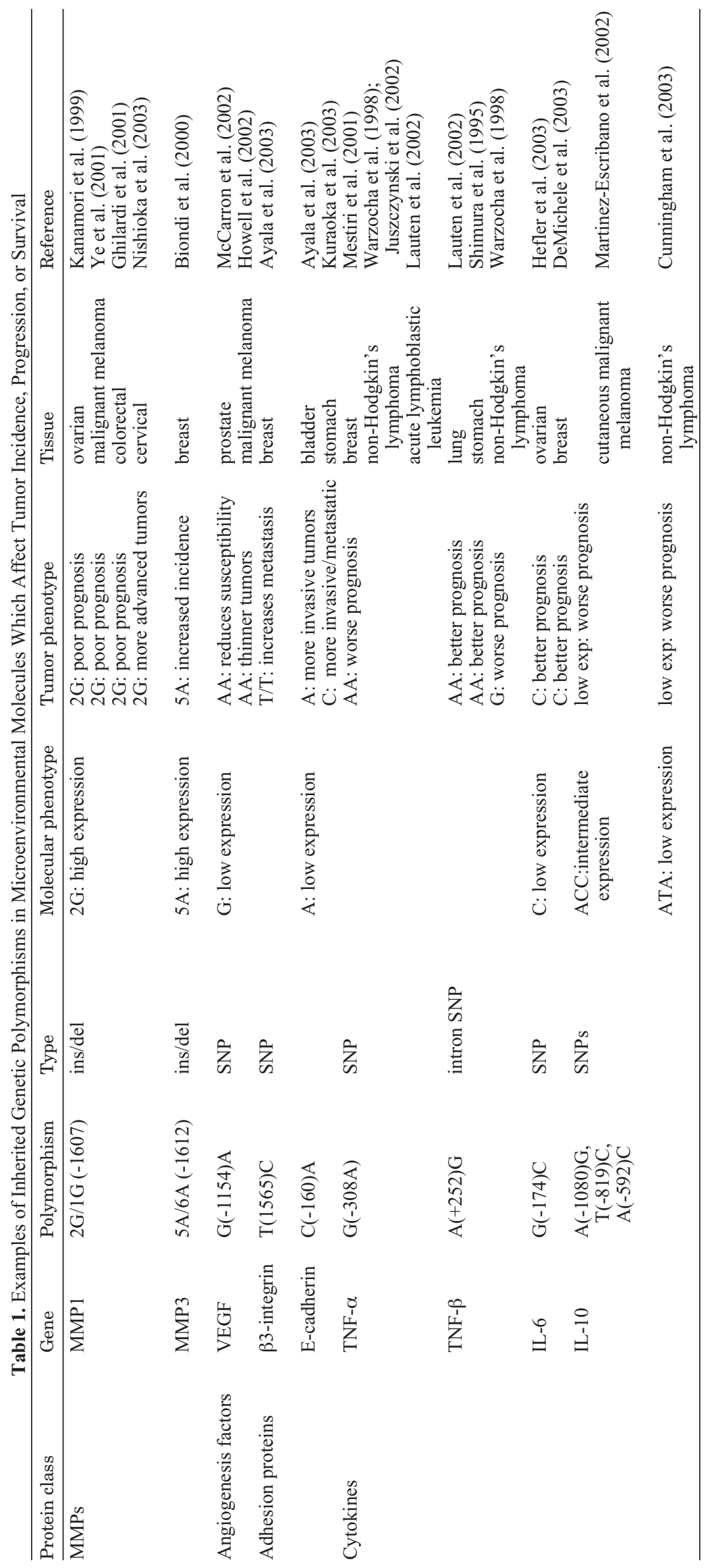


A

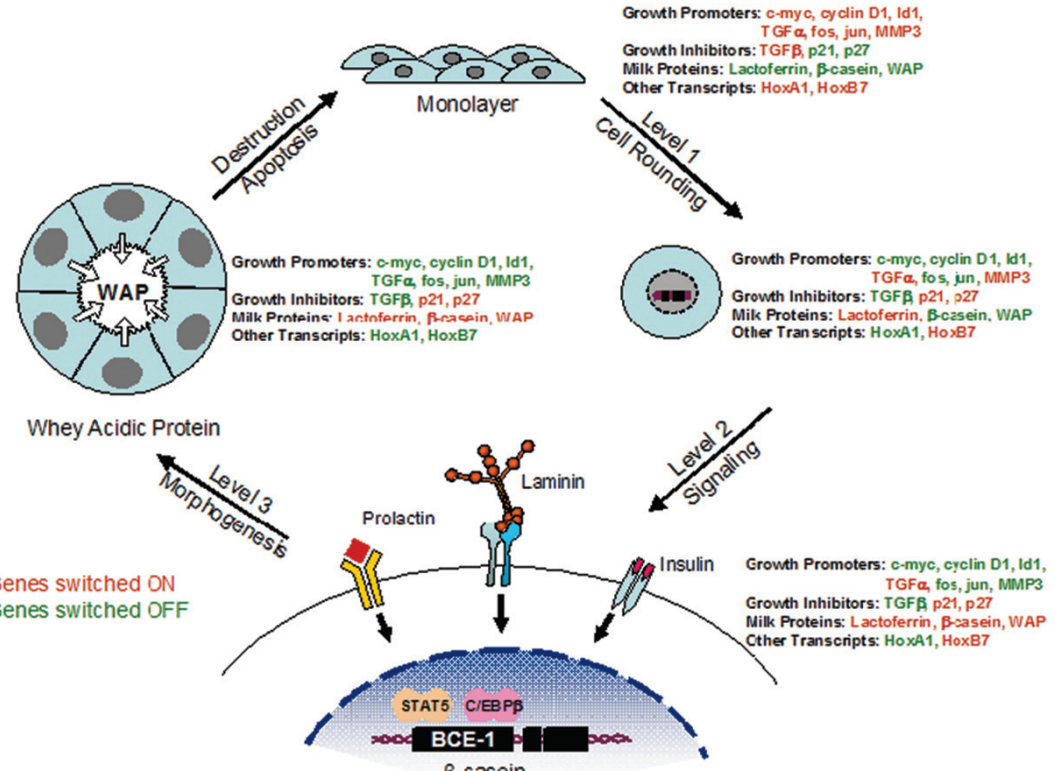

B
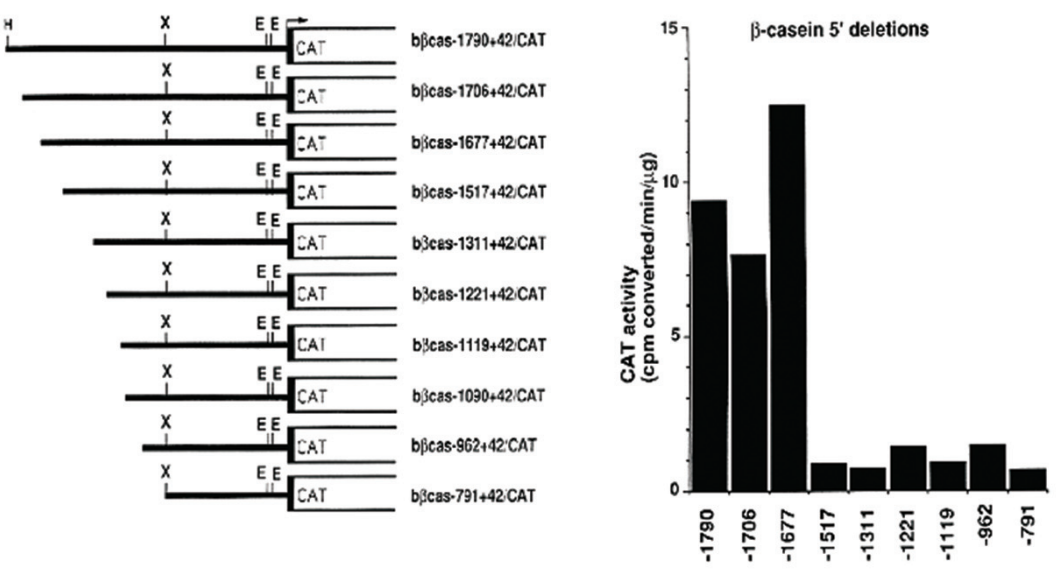

C
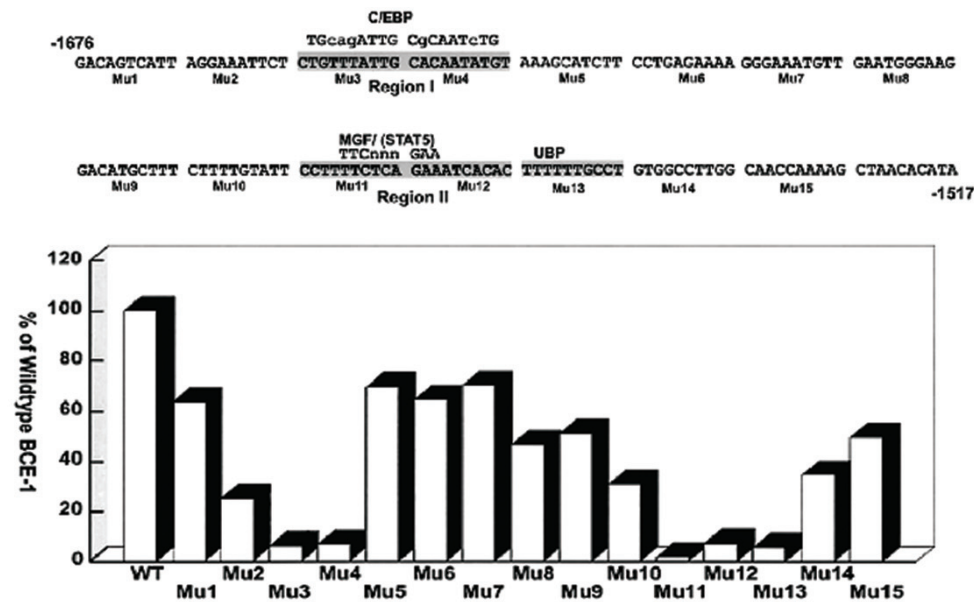

Figure 1. Hierarchical control of tissue function by ECM-dependent cell shape changes, signaling, and morphogenesis. $(A)$ Examples of gene products altered by contact with the ECM and by changes in cellular structure. Studies of MECs cultured in the context of a variety of "designer microenvironments" have demonstrated that cells display distinct behaviors in response to changes in cell shape and ECM composition. In these cultures, the inert substratum, polyHEMA, was used to model cell shape change by itself, whereas purified laminin was used as a ligand that stimulates both cell shape change and integrin-dependent signaling. As cells make the transition from 2D to 3D culture, the expression of distinct cassettes of genes is reciprocally modulated. (B) Deletion analysis of the $\beta$ casein promoter identifies an ECM-response element (BCE-1). (C) Systematic mutational analysis of BCE-1 demonstrates that the $\mathrm{C} / \mathrm{EBP} \beta$ and Stat5 binding sites are required for the ECM-dependent transcriptional response. (Modified, with permission, from Schmidhauser et al. 1992; Roskelley et al. 1995; Myers et al. 1998.) 


\section{INTERROGATION OF NORMAL AND MALIGNANT HUMAN BREAST CELLS IN 3D REVEALS THAT SIGNALING REGULATION DIFFERS IN 2D AND 3D}

Despite differences in the gross anatomy of mouse and human mammary glands, the assays developed for the mouse cells (Barcellos-Hoff et al. 1989) could be used for human cells with an additional bonus: Normal and nonmalignant human breast epithelial cells could be distinguished from premalignant and malignant cells in 3D assays (Petersen et al. 1992). Whereas the normal cells derived from reduction mammoplasty and nonmalignant cell lines became quiescent by day 7 and organized into a replica of human breast acinus with correct tissue polar- ity and proportions, the malignant cells continued to grow, piled up, and formed large, disorganized, tumorlike colonies (Petersen et al. 1992). Using a unique model of human breast cancer progression referred to as HMT3522 (Briand et al. 1987, 1996), we showed that much of the phenotypic difference between the nonmalignant (S1) and malignant (T4-2) cells was due to changes in the levels and functions of surface receptors for ECM molecules and growth factors leading to aberrant activation of a number of signaling pathways.

Using a series of signal transduction inhibitors and dominant-negative mutants, we have delineated the pathways downstream of receptor tyrosine kinases and adhesion receptors that contribute to the malignant phenotype of T4-2 cells (Fig. 2). Using blocking antibodies against
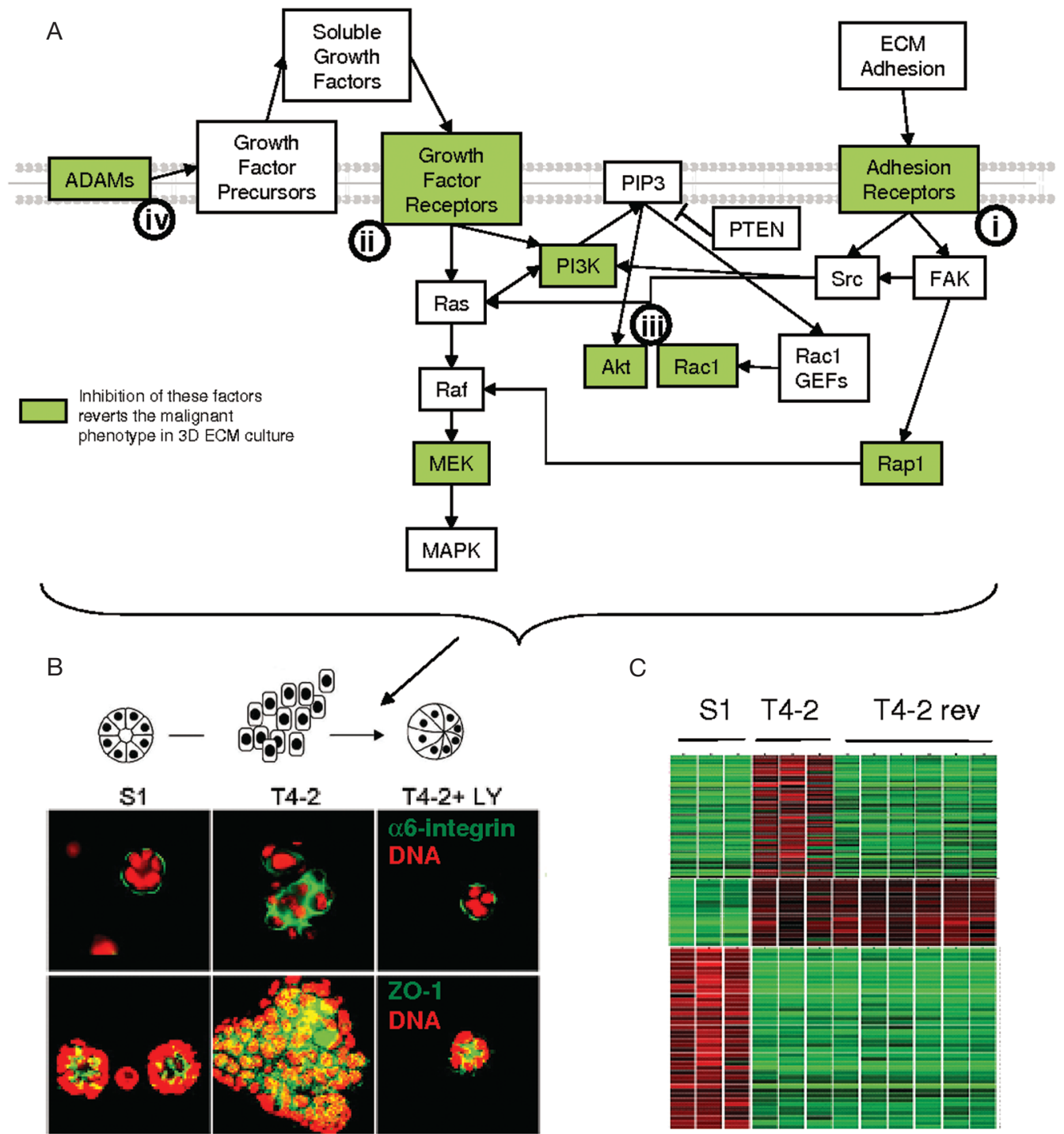

Figure 2. Reversion of the malignant phenotype by modulation of signaling pathways integrated by the ECM. (A) Schematic representation of the signaling pathways downstream of growth factor and adhesion receptors. The activity of some key proteins (green) is required for the maintenance of the malignant phenotype. $(B)$ The malignant phenotype of T4-2 cells may be reverted in 3D ECM culture using inhibitors of the key signaling receptors and their downstream target proteins described above. A representative example (PI3K inhibition) is shown. $\alpha 6$-integrin and ZO-1 are markers of basal and apical polarity, respectively. $(C)$ Hierarchical clustering of Affymetrix microarray data of S1 and T4-2 cells, and T4-2 cells treated with inhibitors of the regulatory proteins shown in $A$. Reversion of the malignant phenotype using diverse inhibitors elicits a common gene expression pattern (P.A. Kenny and M.J. Bissell, unpubl.) (B, Modified, with permission, from Liu et al. 2004.). 
$\beta 1$-integrin (Fig. 2Ai), we defined a requirement for increased ECM signaling via this receptor for the maintenance of the malignant phenotype (Weaver et al. 1997). Furthermore, we defined a role for increased signaling by the EGFR pathway, since inhibitors of this receptor and downstream signaling molecules effected a similar reversion of the malignant phenotype (Fig. 2Aii) (Wang et al. 1998). This reversion encompassed a restoration of growth arrest in response to ECM, the restoration of apicobasal acinar polarity, the reorganization of the actin cytoskeleton, and the formation of adherens junctions (Fig. 2B). Inhibition of PI3-kinase (PI3K) resulted in a similar phenotype (Fig. 2Aiii), and we have dissected the different contributions of two critical PI3K effectors, Rac1 and Akt, to malignancy in this model (Liu et al. 2004). Because these malignant breast cells lack mutations in common proto-oncogenes (P.A. Kenny and M.J. Bissell, unpubl.), we have probed the extracellular effectors upstream of EGFR to identify the key endogenous growth factors that drive the malignant phenotype. Using this approach we have identified two EGFR ligands and a protease required for their activity, and demonstrated that the malignant phenotype may also be reverted by targeting this protease (Fig. 2Aiv) (P.A. Kenny and M.J. Bissell, in prep.). Importantly, inhibition of any of these pathways down-modulates the others, as well as the level of the surface receptors $\beta 1$-integrin, EGFR (Wang et al. 1998), and coxsackievirus and adenovirus receptor, CAR (Anders et al. 2003). This down-modulation does not occur in 2D (Fig. 3) (for review, see Bissell et al. 1999, 2003).

A comparison of cDNA array analysis of nonmalignant and malignant cells indicates that a substantial subset of signaling pathways and programs are altered when cells are placed in 3D (not shown). Furthermore, the array analysis of malignant T4-2 cells treated with these diverse inhibitors indicates that a key subset of genes become "S1-like" in the reverted cells by all the inhibitors tested (Fig. 2C). The contribution of these genes to tissue polarity and growth control is currently under investigation. As such, the reversion model may be used as a screen for how signaling pathways may become integrated as a result of restoration of the tissue architecture. The same approach may be used also for finding new tar-

3DlrBM

\begin{tabular}{|c|c|c|c|c|c|c|c|}
\hline \multirow[b]{2}{*}{$\begin{array}{r}\text { Inhibitor } \\
\text { Added: }\end{array}$} & \multirow{2}{*}{$\begin{array}{l}\text { S1 } \\
80 \\
-\end{array}$} & $\begin{array}{r}\text { T4-2 } \\
90 \\
909 \\
6900\end{array}$ & \multicolumn{2}{|c|}{$\begin{array}{c}\text { T4-2 } \\
\text { "treated" } \\
68\end{array}$} & $\begin{array}{l}\text { T4-2 } \\
000\end{array}$ & \multicolumn{2}{|c|}{$\begin{array}{c}\text { T4-2 } \\
\text { "treated" } \\
\text { סه }\end{array}$} \\
\hline & & - & $\begin{array}{c}\beta 1- \\
\text { integrin } \\
\text { inhibitor }\end{array}$ & $\begin{array}{c}\text { EGFR } \\
\text { Inhibitor }\end{array}$ & - & $\begin{array}{c}\beta 1- \\
\text { integrin } \\
\text { inhibitor }\end{array}$ & $\begin{array}{c}\text { EGFR } \\
\text { Inhibitor. }\end{array}$ \\
\hline $\begin{array}{c}\text { p1-integrin } \\
\text { total levels }\end{array}$ & + & +++ & + & + & +++ & +++ & +++ \\
\hline $\begin{array}{r}\text { EGFR } \\
\text { total levels }\end{array}$ & + & ++++ & + & + & ++++ & +++ & ++++ \\
\hline $\begin{array}{r}\mathrm{EGFR}^{*} \\
\text { activated }\end{array}$ & + & ++++ & + & + & ++++ & ++++ & + \\
\hline
\end{tabular}

Figure 3. $\beta 1$-integrin and EGFR protein levels and activities are coordinately modulated in HMT3522 cells in 3D ECM. This reciprocal cross-modulation is not observed in cells cultured on tissue culture plastic. (Reprinted, with permission, from Bissell et al. 1999 [C AACR].) gets for breast cancer therapy, and a number of laboratories, including ours, are using these assays for such studies at present.

\section{TISSUE POLARITY ALSO REGULATES RESPONSE AND RESISTANCE TO CHEMOTHERAPEUTIC AGENTS}

It has long been noted that tumor cells change their response to radiation and chemical treatments when they are aggregated (Kerbel et al. 1996; Durand and Olive 2001). There are well-known pathways by which tumor cells can become resistant to chemotherapy. We reasoned that since tissue structure is so fundamental to phenotypic behavior of tumor cells, one additional mode of resistance could be due to the changes that occur as a result of reestablishment of tissue polarity. That this is indeed the case was shown in a series of experiments we reported in 2002 (Weaver et al. 2002). Briefly, normal and malignant human breast cells become resistant to induction of apoptosis by six different chemotherapeutic agents when they are correctly polarized in 3D (Fig. 4). Both cell types are equally susceptible to cell death when cultivated on tissue culture plastic. That tissue polarity rather than differences in mutation, growth rate, or 3-dimensionality per se is responsible for the observed differences was shown using some of the techniques developed in the laboratory and described above. If normal cells are disorganized in 3D they die. If tumor cells are reverted in laminin-rich ECM, they become resistant; if they are growth-arrested in collagen-I gels where breast tissue polarity is reversed, they still die. These observations were traced to the establishment of the correct tissue polarity through involvement of hemi-desmosomes and $\alpha 6 / \beta 4$-integrins (for further details, see Weaver et al. 2002). This is another clear example of the importance of the microenvironment and tissue architecture in function and dysfunction.
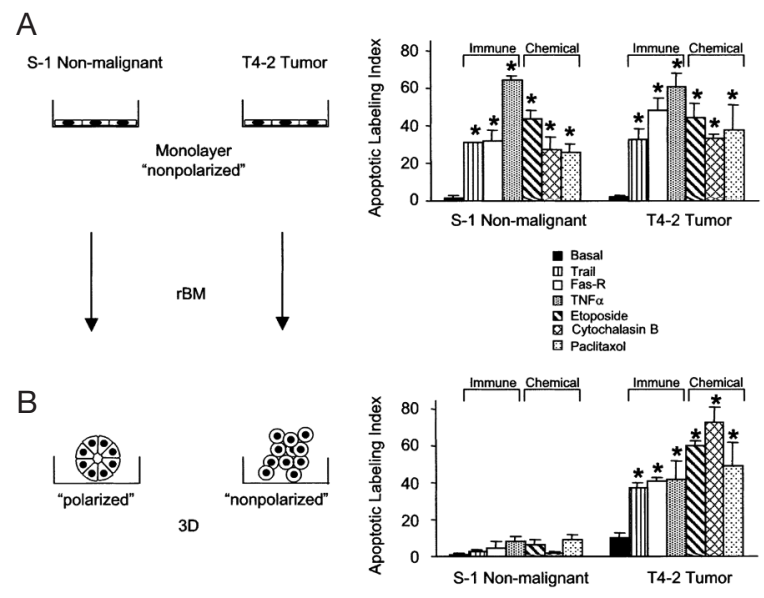

Figure 4. Only nonmalignant cells within mammary acini are resistant to apoptosis. Apoptotic labeling indices calculated for S-1 and T4-2 cells treated with Trail peptide $(1 \mu \mathrm{g} / \mathrm{ml})$, anti-FAS $\mathrm{mAb}$ (IgM CH-11, $2 \mu \mathrm{g} / \mathrm{ml})$, TNF- $\alpha$ (100 nM), etoposide (50 $\mu \mathrm{M})$, cytochalasin B $(1 \mu \mathrm{M})$, or paclitaxol $(120 \mathrm{nM})$. Cells were treated $(A)$ as monolayers on a thin coat of collagen I for $24 \mathrm{hr}$ or $(B)$ as 3D structures in rBM for $96 \mathrm{hr}$. (Reprinted, with permission, from Weaver et al. 2002 [C Elsevier].) 


\section{METALLOPROTEINASES AS ONCOGENES; NORMAL STROMA AS A TUMOR SUPPRESSOR}

Matrix metalloproteinases (MMPs) regulate a number of pathways relevant to cancer biology, including proliferation, differentiation, apoptosis, migration, and invasion (Egeblad and Werb 2002). Establishment of a causal relationship between MMP overexpression and tumor progression has prompted the development of several MMP inhibitors as anticancer therapeutics, and although clinical trials in which these agents were used to treat late-stage tumors have been disappointing, accumulating evidence suggests that the tumor-promoting activity of MMPs may be most important in the earliest stages of tumor development (Coussens et al. 2002; Egeblad and Werb 2002). We previously observed that transgenic mice expressing an autoactivated form of MMP-3 (stromelysin-1) under control of the whey acidic protein promoter (WAP) to direct expression in mammary epithelial cells in mid-pregnancy (Sympson et al. 1994) develop invasive, genomically unstable mammary tumors (Sternlicht et al. 1999). Development of a culture assay to dissect these effects revealed that treatment with MMP-3 causes mouse mammary epithelial cells to alter cellular morphology, decrease cell-cell interactions, increase motility and invasiveness, down-regulate epithelial cytokeratins, and up-regulate mesenchymal vimentin (Boudreau et al. 1995; Lochter et al. 1997a,b), characteristics of epithelial-to-mesenchymal transition (EMT) that facilitate tumor invasion and metastasis (Thiery 2002). The genomic alterations induced by MMP-3 are strikingly nonrandom, with common patterns of genomic deletions found on chromosome 4 in tumor tissue derived from the WAP-MMP-3 transgenic mice (Fig. 5A) and in cultured mouse mammary epithelial cells exposed to MMP-3 (Fig. 5B) (Sternlicht et al. 1999; Radisky et al. 2005).

A common mechanism underlying both induction of EMT and the development of genomic instability by MMP-3 was suggested by the concomitant appearance of EMT (Fig. 6A) with increased resistance to N-(phosphon-

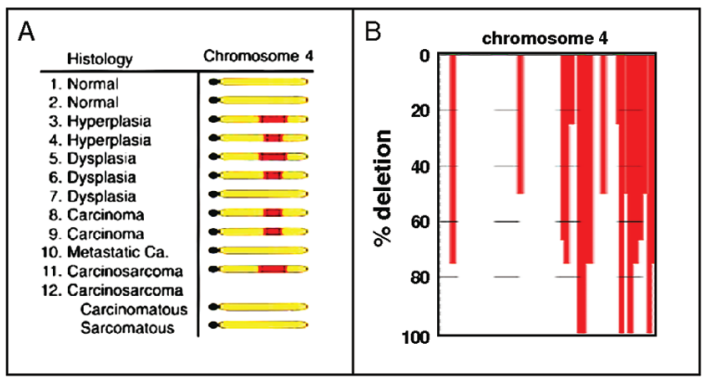

Figure 5. Nonrandom patterns of genomic instability induced by treatment with MMP-3. (A) Analysis of normal and tumor tissue from WAP-MMP-3 transgenic mice by cytogenetic comparative genomic hybridization $(\mathrm{CGH})$ reveals common patterns of deletions (red) in chromosome 4. (B) Cultured SCp2 mouse mammary epithelial cells exposed to MMP-3 become genomically unstable and show deletions in chromosome 4, as revealed by array-based CGH. ( $A$, Adapted from Sternlicht et al. 1999; $B$, adapted from Radisky et al. 2005.)
acetyl)-L-aspartate (PALA) (Fig. 6B) (Johnson et al. 1976), as resistance to PALA is acquired through amplification of the CAD gene (Wahl et al. 1979; Radisky et al. 2005). Our investigations revealed that both the MMP-3induced phenotypic alterations (e.g., induction of EMT) and genetic changes (e.g., genomic instability) were caused by increases in cellular reactive oxygen species (ROS). Cultured mouse mammary epithelial cells treated with MMP-3 showed significantly increased oxidative DNA damage that was inhibited by treatment with ROS inhibitor N-acetyl cysteine (NAC) and, consistent with the implication that the ROS-mediated DNA damage was related to the induction of genomic instability, we found that NAC inhibited the MMP-3-induced acquisition of PALA resistance, and that elevating cellular redox levels in the absence of MMP-3 by treatment with $\mathrm{H}_{2} \mathrm{O}_{2}$ was sufficient to stimulate PALA resistance (Radisky et al. 2005). ROS have been implicated as secondary signaling intermediates that control cellular phenotype (Droge 2002; Puri et al. 2002; Finkel 2003), and we found that MMP-3-induced ROS were both necessary and sufficient to induce the EMT phenotypic alterations in target mammary epithelial cells (Radisky et al. 2005).

Previous studies (Kheradmand et al. 1998; Werner and Werb 2002) showed that alterations in cell morphology, a process related to MMP-3-induced EMT, can lead to increased cellular ROS through a Rac1-dependent mechanism. Using pull-down activity assays, we found that MMP-3 treatment stimulated an increase in Rac1 activity and the induction of a higher-molecular-weight form of active Rac1 (Fig. 6C). Rac1b is a highly activated splice isoform of Rac1 that has been found in breast and colorectal tumors (Matos et al. 2003; Fiegen et al. 2004). Quantitative RT-PCR using oligonucleotide primers specific for the Raclb isoform performed on cells that were treated for up to 4 days with MMP-3 showed a progressively increasing expression of Raclb for as long as MMP-3 was present, and that Rac $1 b$ levels fell off rapidly after MMP-3 withdrawal (Fig. 6D). Consistent with the implication that the MMP-3-induced alterations in Rac1b expression are the trigger for EMT, we observed that expression of Snail and vimentin paralleled the expression of Raclb (Radisky et al. 2005), and that inhibition of Raclb expression by RNAi blocked the induction of EMT by MMP-3 (Fig. 6E).

A contrast can be drawn between the phenotypic consequences of MMP-3/Rac1b-induced ROS (i.e., induction of EMT) and the genetic consequences (i.e., DNA damage and genomic instability). Although it seems likely that MMP-3-induced genomic instability is a nonspecific or pathological response, we conjecture that induction of EMT by MMP-3/Rac1b-produced ROS is caused by specific activation of select signaling pathways; indeed, we found that MMP-3-induced ROS were both necessary and sufficient for induction of the Snail transcription factor, implicated previously as a key mediator of EMT (Nieto 2002; Thiery 2002). Although we have shown that MMP3 can directly cause malignant transformations, it is noteworthy that MMPs are involved in many normal developmental processes, and that genetic deficiency of MMPs 


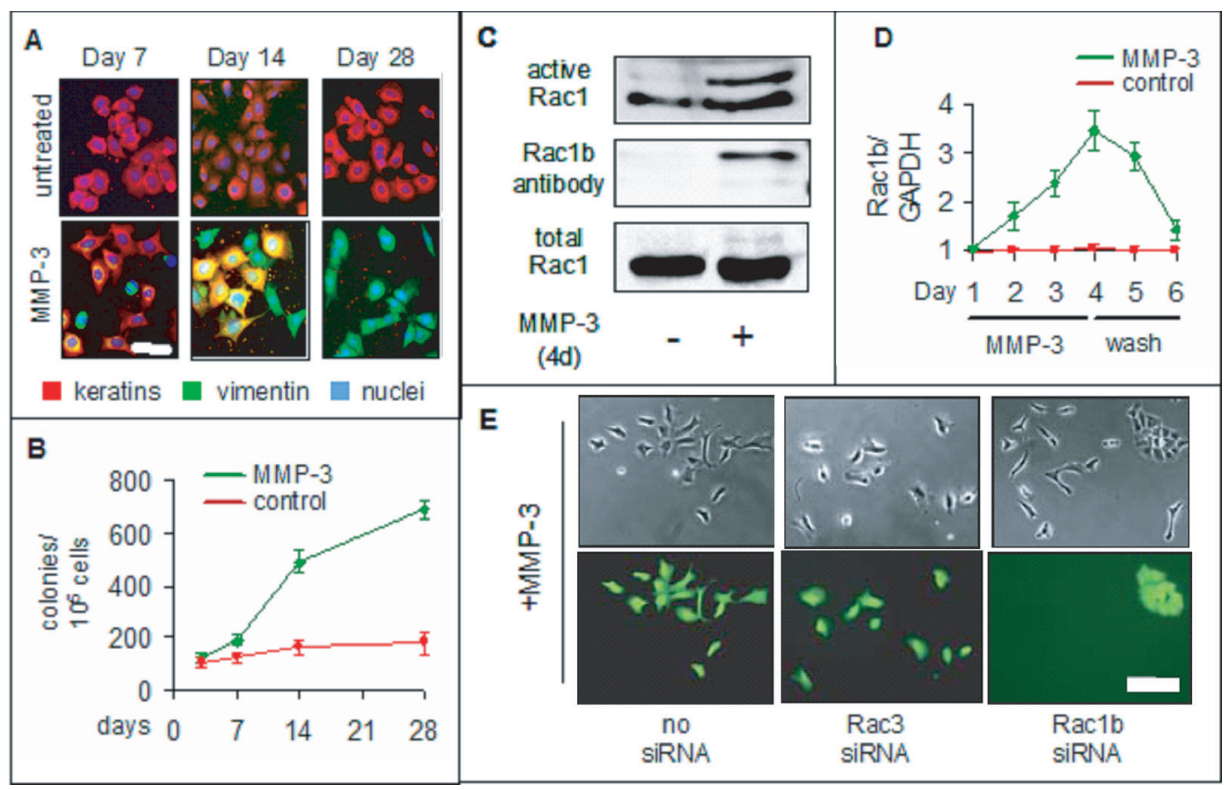

Figure 6. Induction of EMT and genomic instability by treatment with MMP-3: Role of Rac1b. (A) MMP-3-treated SCp2 cells, stained for cytokeratins (red), vimentin (green), and DNA (blue); bar, $50 \mathrm{~mm}$. (B) Induction of PALA resistance by MMP-3 (green diamonds, MMP-3; red squares, untreated). (C) Treatment with MMP-3 stimulates production of Rac1b, a highly activated splice isoform of Rac1. (Top) Active Rac species as assessed by PAK pulldown assay; (middle) total cell lysates probed with antibody raised against Rac1b splice insertion; (bottom) total cell lysates probed with Rac1 antibody, showing low levels of Raclb expression relative to Rac1 in lysate from treated cells. $(D)$ Time course of Rac1b expression in response to MMP-3 treatment and withdrawal. MMP3 treatment (days 1-4) and washout (days 5-6) (green diamonds, MMP-3-treated; red squares, untreated). (E) Specific suppression of Rac1b by siRNA blocks MMP3-induced EMT. (Adapted from Radisky et al. 2005.)

can lead to an array of developmental abnormalities (Sternlicht and Werb 2001). In this regard, it is relevant that many other developmental signaling molecules have also been found to facilitate tumor progression, including BMPs, TGF- $\beta$ (Waite and Eng 2003), Wnts (Moon et al. 2002), Notch (Radtke and Raj 2003), and Hedgehog (Pasca di Magliano and Hebrok 2003). The investigation of the tumor-promoting effects of these factors has been facilitated by an understanding of the cellular signaling mechanisms by which they operate, and our new understanding of the MMP-3-induced signaling pathways provides insight into this parallel process. Since our initial studies on MMP3-induced tumorigenesis, two further extracellular proteases, MT1-MMP and matriptase, have been causally implicated in tumorigenesis using transgenic models (Ha et al. 2001; List et al. 2005).

Demonstrating that these stromal alterations actually facilitate tumor progression is difficult in human studies; however, a number of recently developed animal models address this point and show that genetic lesions in the stroma can make a positive and even causative contribution to epithelial tumorigenesis. Conditional ablation of the Tgfbr2 gene in fibroblasts induced the onset of neoplasia in the prostate and squamous cell carcinoma of the forestomach (Fig. 7) (Bhowmick et al. 2004). It has also been shown that growth of MCF7 xenografts is significantly enhanced in SCID mice null for p53. $\mathrm{p} 53^{+/-}$mice exhibit intermediate kinetics of tumor growth and, importantly, loss of the wild-type $\mathrm{p} 53$ allele was detected in the tumor stroma arising in six of eight tumors in the heterozygous mice (Kiaris et al. 2005).

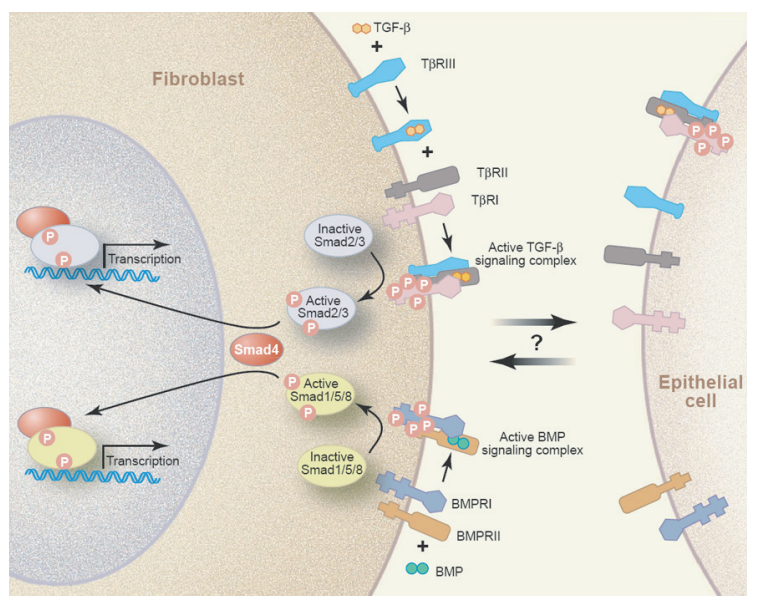

Figure 7. Signaling pathways in stromal cells activated by TGF$\beta$ and BMP prevent tumor formation in epithelia. TGF- $\beta$ signaling can be initiated by association with type III TGF- $\beta$ receptors prior to formation of an active kinase complex containing receptor types I and II. The active TGF- $\beta$ signaling complex phosphorylates receptor-regulated R-SMADs such as Smad2 and Smad3, which then bind to common partner co-SMADs such as Smad4. The resulting activated complex can bind to specific DNA sequences and influence the transcription of many tissuespecific genes. Similarly, BMP family members form an active BMP signaling complex, which phosphorylates Smads 1, 5, and 8. These activated R-SMADs then associate with Smad4 to form an active transcriptional complex. Loss of T $\beta$ RII, Smad4, or BMPRI in stromal cells can stimulate the formation of tumors in adjacent epithelium, although the signals involved in this process have not yet been identified. (Reprinted, with permission, from Radisky and Bissell 2004 [C AAAS].) 


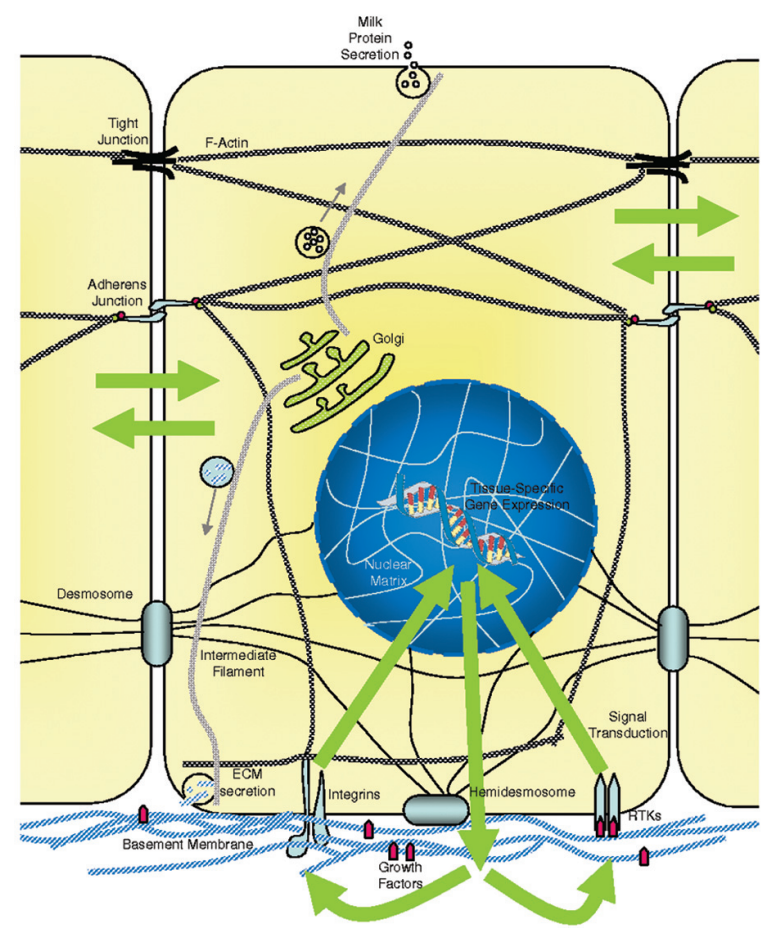

Figure 8. Dynamic reciprocity: The whole is greater than the sum of its parts. Gene expression and function of differentiated tissues is an emergent property arising from the bidirectional flow of biochemical and mechanical signals between the ECM and the nucleus, transduced by transmembrane receptors, signaling molecules, and cytoskeletal elements. In the last analysis, however, the organ itself is the unit of function (Bissell and Hall 1987).

That not only stroma, but the different epithelial cell types, and in fact all cell types that make up the architecture of the organs (Fig. 8), play important roles in the integrity of the function of that organ can be demonstrated further with studies on the role of myoepithelial cells in establishment of tissue polarity in breast acini (Gudjonsson et al. 2002; Adriance et al. 2005).

\section{INHERITED POLYMORPHISMS IN GENES ENCODING MICROENVIRONMENTAL PROTEINS THAT MAY ALTER CANCER SUSCEPTIBILITY AND/OR PROGRESSION KINETICS}

Loss of function of tumor suppressor genes such as RB, BRCA1, BRCA2, and CHK2 is a critical component of a large proportion of familial cancers. However, it is clear that other low-penetrance alleles also contribute to this polygenic disease in the wider population. Several casecontrol studies have examined the effects of germ-line polymorphisms in genes encoding proteins present in the tissue microenvironment to determine whether variation in any of these genes contributes to an increased risk of incidence or progression in several cancers. Such polymorphisms may alter the coding sequence of the protein, with resultant effects on its activity, or they may occur in noncoding regions of the gene, where they may lead to al- tered levels of gene expression and/or alternative splicing by creating or deleting consensus binding sites for nucleic acid interacting proteins. Although there has been an explosion of interest in this field, it is important to note that many of these studies are relatively small and, despite achieving statistical significance at the threshold set by the investigators, remain to be confirmed in larger studies. We believe that it is important to be fully cognizant of the statistical problems inherent in this methodology, particularly of the propensity of these studies to produce false positives (Risch 2000; Pharoah et al. 2004).

For the purposes of this paper, we confine our discussion to those SNPs which have been demonstrated (or at least imputed) to exert an effect on protein expression or activity. Several of these studies have been reviewed in detail elsewhere (Balasubramanian et al. 2002; Loktionov 2004) and are summarized in Table 1. Polymorphic changes have been reported in genes encoding growth factors, adhesion receptors, proteases, and cytokines - proteins that play crucial roles in the intercellular milieu. Each of these proteins has been implicated in neoplasia. Several of these SNPs are found in the promoter regions of their respective genes and have been associated with alterations in the mRNA expression level for that allele. Although it remains to be seen how many of these findings will be reproduced in larger, independent populations, these data support the hypothesis that dose-dependent alterations in components of the tissue microenvironment may play causative roles in tumorigenesis or may facilitate the neoplastic progression of an incipient tumor cell.

In addition, the importance of epithelial-stromal interactions for cancer progression is underlined by the detection of clones of mutant stromal cells, the expansion of which has been favored by the acquired mutation(s). Several global studies using microdissected samples of tumor epithelium and stroma with subsequent analysis of loss of heterozygosity or allelic imbalance have shown that distinct genetic alterations occur in the epithelial and stromal compartments. Somatically acquired genetic alterations in the stroma have been reported in cancers of the breast (Moinfar et al. 2000; Kurose et al. 2001; Ellsworth et al. 2004; Fukino et al. 2004), colon (Wernert et al. 2001), bladder (Paterson et al. 2003), prostate (McCarthy et al. 2004), and ovary (Tuhkanen et al. 2004). These genomic studies provide a bird's-eye view of the nature and scale of the differing genetic lesions present in the epithelial and stromal compartments. A greater insight into the coselected mechanisms that drive tumor progression will come from a detailed molecular analysis of these regions, and recent studies have shown that some of the players most familiar from epithelial tumorigenesis are also altered in the stroma. Mutations in p53 and PTEN have been reported in the stroma of breast carcinomas (Kurose et al. 2002), and mutations in EGFR also have been detected in this compartment (Weber et al. 2005). Given the number of mutational and cytogenetic abnormalities detected in stroma to date, it seems likely that epigenetic alterations in stromal cells might also contribute to tumorigenesis. Collectively, these striking data suggest that 
there is a strong selective pressure in tumors of different epithelial origins for the coevolution of a clonal stromal compartment.

\section{ACKNOWLEDGMENTS}

These investigations were supported by grants from the U.S. Department of Energy, Office of Biological and Environmental Research (DE-AC03 SF0098), National Cancer Institute (2 R01 CA064786-09), and an Innovator Award from the Department of Defense Breast Cancer Research Program (BC012005) to M.J.B; and from the National Cancer Institute (CA57621) to M.J.B. and Zena Werb; and by postdoctoral training fellowships (Susan G. Komen Breast Cancer Foundation \#2000-223 and DOD BCRP DAMD17-00-1-0224 to P.A.K. and American Cancer Society PF-02-009-01-DDC to D.C.R.).

\section{REFERENCES}

Adriance M.C., Inman J.L., Petersen O.W., and Bissell M.J. 2005. Myoepithelial cells: Good fences make good neighbors. Breast Cancer Res. 7: 190.

Allinen M., Beroukhim R., Cai L., Brennan C., Lahti-Domenici J., Huang H., Porter D., Hu M., Chin L., Richardson A., Schnitt S., Sellers W.R., and Polyak K. 2004. Molecular characterization of the tumor microenvironment in breast cancer. Cancer Cell 6: 17.

Anders M., Hansen R., Ding R.X., Rauen K.A., Bissell M.J., and Korn W.M. 2003. Disruption of 3D tissue integrity facilitates adenovirus infection by deregulating the coxsackievirus and adenovirus receptor. Proc. Natl. Acad. Sci. 100: 1943.

Ayala F., Corral J., Gonzalez-Conejero R., Sanchez I., Moraleda J.M., and Vicente V. 2003. Genetic polymorphisms of platelet adhesive molecules: Association with breast cancer risk and clinical presentation. Breast Cancer Res. Treat. 80: 145.

Balasubramanian S.P., Brown N.J., and Reed M.W. 2002. Role of genetic polymorphisms in tumour angiogenesis. $B r . J$. Cancer 87: 1057.

Barcellos-Hoff M.H., Aggeler J., Ram T.G., and Bissell M.J. 1989. Functional differentiation and alveolar morphogenesis of primary mammary cultures on reconstituted basement membrane. Development 105: 223.

Bhowmick N.A., Chytil A., Plieth D., Gorska A.E., Dumont N., Shappell S., Washington M.K., Neilson E.G., and Moses H.L. 2004. TGF-beta signaling in fibroblasts modulates the oncogenic potential of adjacent epithelia. Science 303: 848 .

Bingle L., Brown N.J., and Lewis C.E. 2002. The role of tumourassociated macrophages in tumour progression: Implications for new anticancer therapies. J. Pathol. 196: 254.

Biondi M.L., Turri O., Leviti S., Seminati R., Cecchini F., Bernini M., Ghilardi G., and Guagnellini E. 2000. MMP1 and MMP3 polymorphisms in promoter regions and cancer. Clin. Chem. 46: 2023.

Bissell M.J. 1981. The differentiated state of normal and malignant cells or how to define a "normal" cell in culture. Int. Rev. Cytol. 70: 27.

Bissell M.J. and Hall H.G. 1987. Form and function in the mammary gland: The role of extracellular matrix. In The mammary gland (ed. M.C. Neville and C.W. Daniel), p. 97. Plenum Publishing, New York.

Bissell M.J., Hall H.G., and Parry G. 1982. How does the extracellular matrix direct gene expression? J. Theor. Biol. 99: 31 .

Bissell M.J., Rizki A., and Mian I.S. 2003. Tissue architecture: The ultimate regulator of breast epithelial function. Curr. Opin. Cell Biol. 15: 753.

Bissell M.J., Weaver V.M., Lelievre S.A., Wang F., Petersen O.W., and Schmeichel K.L. 1999. Tissue structure, nuclear organization, and gene expression in normal and malignant breast. Cancer Res. (suppl. 7) 59: 1757.
Blau H.M. and Baltimore D. 1991. Differentiation requires continuous regulation. J. Cell Biol. 112: 781.

Boudreau N., Sympson C.J., Werb Z., and Bissell M.J. 1995. Suppression of ICE and apoptosis in mammary epithelial cells by extracellular matrix. Science 267: 891.

Briand P., Petersen O.W., and Van Deurs B. 1987. A new diploid nontumorigenic human breast epithelial cell line isolated and propagated in chemically defined medium. In Vitro Cell. Dev. Biol. 23: 181.

Briand P., Nielsen K.V., Madsen M.W., and Petersen O.W. 1996. Trisomy $7 \mathrm{p}$ and malignant transformation of human breast epithelial cells following epidermal growth factor withdrawal. Cancer Res. 56: 2039.

Camps J.L., Chang S.M., Hsu T.C., Freeman M.R., Hong S.J., Zhau H.E., von Eschenbach A.C., and Chung L.W. 1990. Fibroblast-mediated acceleration of human epithelial tumor growth in vivo. Proc. Natl. Acad. Sci. 87: 75.

Cardoso W.V. 2001. Molecular regulation of lung development. Annu. Rev. Physiol. 63: 471.

Carrel A. 1908. Results of the transplantation of blood vessels, organs and limbs. J. Am. Med. Assoc. 51: 1662.

. 1911. Rejuvenation of cultures of tissues. J. Am. Med. Assoc. 57: 1611.

Coussens L.M., Fingleton B., and Matrisian L.M. 2002. Matrix metalloproteinase inhibitors and cancer: Trials and tribulations. Science 295: 2387.

Cunha G.R., Ricke W., Thomson A., Marker P.C., Risbridger G., Hayward S.W., Wang Y.Z., Donjacour A.A., and Kurita T. 2004. Hormonal, cellular, and molecular regulation of normal and neoplastic prostatic development. J. Steroid Biochem. Mol. Biol. 92: 221.

Cunningham L.M., Chapman C., Dunstan R., Bell M.C., and Joske D.J. 2003. Polymorphisms in the interleukin 10 gene promoter are associated with susceptibility to aggressive nonHodgkin's lymphoma. Leuk. Lymphoma 44: 251.

DeCosse J.J., Gossens C.L., Kuzma J.F., and Unsworth B.R. 1973. Breast cancer: Induction of differentiation by embryonic tissue. Science 181: 1057.

DeMichele A., Martin A.M., Mick R., Gor P., Wray L., KleinCabral M., Athanasiadis G., Colligan T., Stadtmauer E., and Weber B. 2003. Interleukin-6-174G $\rightarrow$ C polymorphism is associated with improved outcome in high-risk breast cancer. Cancer Res. 63: 8051.

Dolberg D.S. and Bissell M.J. 1984. Inability of Rous sarcoma virus to cause sarcomas in the avian embryo. Nature 309: 552.

Droge W. 2002. Free radicals in the physiological control of cell function. Physiol. Rev. 82: 47.

Durand R.E. and Olive P.L. 2001. Resistance of tumor cells to chemo- and radiotherapy modulated by the three-dimensional architecture of solid tumors and spheroids. Methods Cell Biol. 64: 211.

Dvorak H.F. 1986. Tumors: Wounds that do not heal. Similarities between tumor stroma generation and wound healing. $N$. Engl. J. Med. 315: 1650.

Egeblad M. and Werb Z. 2002. New functions for the matrix metalloproteinases in cancer progression. Nat. Rev. Cancer 2: 161.

Ellsworth D.L., Ellsworth R.E., Love B., Deyarmin B., Lubert S.M., Mittal V., and Shriver C.D. 2004. Genomic patterns of allelic imbalance in disease free tissue adjacent to primary breast carcinomas. Breast Cancer Res. Treat. 88: 131.

Emerman J.T. and Pitelka D.R. 1977. Maintenance and induction of morphological differentiation in dissociated mammary epithelium on floating collagen membranes. In Vitro 13: 316.

Ferguson M.W. and O'Kane S. 2004. Scar-free healing: From embryonic mechanisms to adult therapeutic intervention. Philos. Trans. R. Soc. Lond. B Biol. Sci. 359: 839.

Fiegen D., Haeusler L.C., Blumenstein L., Herbrand U., Dvorsky R., Vetter I.R., and Ahmadian M.R. 2004. Alternative splicing of Rac1 generates Rac1b, a self-activating GTPase. J. Biol. Chem. 279: 4743.

Finkel T. 2003. Oxidant signals and oxidative stress. Curr. Opin. Cell Biol. 15: 247.

Fukino K., Shen L., Matsumoto S., Morrison C.D., Mutter G.L., 
and Eng C. 2004. Combined total genome loss of heterozygosity scan of breast cancer stroma and epithelium reveals multiplicity of stromal targets. Cancer Res. 64: 7231.

Ghilardi G., Biondi M.L., Mangoni J., Leviti S., DeMonti M., Guagnellini E., and Scorza R. 2001. Matrix metalloproteinase-1 promoter polymorphism $1 \mathrm{G} / 2 \mathrm{G}$ is correlated with colorectal cancer invasiveness. Clin. Cancer Res. 7: 2344.

Grobstein C. 1964. Cytodifferentiation and its controls. Science 143: 643.

Gudjonsson T., Ronnov-Jessen L., Villadsen R., Rank F., Bissell M.J., and Petersen O.W. 2002. Normal and tumor-derived myoepithelial cells differ in their ability to interact with luminal breast epithelial cells for polarity and basement membrane deposition. J. Cell Sci. 115: 39.

Ha H.Y., Moon H.B., Nam M.S., Lee J.W., Ryoo Z.Y., Lee T.H., Lee K.K., So B.J., Sato H., Seiki M., and Yu D.Y. 2001. Overexpression of membrane-type matrix metalloproteinase-1 gene induces mammary gland abnormalities and adenocarcinoma in transgenic mice. Cancer Res. 61: 984.

Harach H.R., Franssila K.O., and Wasenius V.M. 1985. Occult papillary carcinoma of the thyroid. A "normal" finding in Finland. A systematic autopsy study. Cancer 56: 531.

Hayashi N., Cunha G.R., and Wong Y.C. 1990. Influence of male genital tract mesenchymes on differentiation of Dunning prostatic adenocarcinoma. Cancer Res. 50: 4747.

Hefler L.A., Grimm C., Ackermann S., Malur S., Radjabi-Rahat A.R., Leodolter S., Beckmann M.W., Zeillinger R., Koelbl H., and Tempfer C.B. 2003. An interleukin-6 gene promoter polymorphism influences the biological phenotype of ovarian cancer. Cancer Res. 63: 3066.

Hochedlinger K., Blelloch R., Brennan C., Yamada Y., Kim M., Chin L., and Jaenisch R. 2004. Reprogramming of a melanoma genome by nuclear transplantation. Genes Dev. 18: 1875.

Howell W.M., Bateman A.C., Turner S.J., Collins A., and Theaker J.M. 2002. Influence of vascular endothelial growth factor single nucleotide polymorphisms on tumour development in cutaneous malignant melanoma. Genes Immun. 3: 229.

Howlett A.R., Carter V.C., Martin G.S., and Bissell M.J. 1988. pp60v-src tyrosine kinase is expressed and active in sarcomafree avian embryos microinjected with Rous sarcoma virus. Proc. Natl. Acad. Sci. 85: 7587.

Johnson R.K., Inouye T., Goldin A., and Stark G.R. 1976. Antitumor activity of $\mathrm{N}$-(phosphonacetyl)-L-aspartic acid, a transition-state inhibitor of aspartate transcarbamylase. Cancer Res. 36: 2720.

Juszczynski P., Kalinka E., Bienvenu J., Woszczek G., Borowiec M., Robak T., Kowalski M., Lech-Maranda E., Baseggio L., Coiffier B., Salles G., and Warzocha K. 2002. Human leukocyte antigens class II and tumor necrosis factor genetic polymorphisms are independent predictors of nonHodgkin lymphoma outcome. Blood 100: 3037.

Kanamori Y., Matsushima M., Minaguchi T., Kobayashi K., Sagae S., Kudo R., Terakawa N., and Nakamura Y. 1999. Correlation between expression of the matrix metalloproteinase-1 gene in ovarian cancers and an insertion/deletion polymorphism in its promoter region. Cancer Res. 59: 4225.

Kerbel R.S., St. Croix B., Florenes V.A., and Rak J. 1996. Induction and reversal of cell adhesion-dependent multicellular drug resistance in solid breast tumors. Hum. Cell 9: 257.

Kheradmand F., Werner E., Tremble P., Symons M., and Werb Z. 1998. Role of Rac1 and oxygen radicals in collagenase-1 expression induced by cell shape change. Science 280: 898 .

Kiaris H., Chatzistamou I., Trimis G., Frangou-Plemmenou M., Pafiti-Kondi A., and Kalofoutis A. 2005. Evidence for nonautonomous effect of p53 tumor suppressor in carcinogenesis. Cancer Res. 65: 1627.

Kuraoka K., Oue N., Yokozaki H., Kitadai Y., Ito R., Nakayama H., and Yasui W. 2003. Correlation of a single nucleotide polymorphism in the E-cadherin gene promoter with tumorigenesis and progression of gastric carcinoma in Japan. Int. J. Oncol. 23: 421.

Kurose K., Gilley K., Matsumoto S., Watson P.H., Zhou X.P., and Eng C. 2002. Frequent somatic mutations in PTEN and TP53 are mutually exclusive in the stroma of breast carcinomas. Nat. Genet. 32: 355.

Kurose K., Hoshaw-Woodard S., Adeyinka A., Lemeshow S., Watson P.H., and Eng C. 2001. Genetic model of multi-step breast carcinogenesis involving the epithelium and stroma: Clues to tumour-microenvironment interactions. Hum. Mol. Genet. 10: 1907.

Lauten M., Matthias T., Stanulla M., Beger C., Welte K., and Schrappe M. 2002. Association of initial response to prednisone treatment in childhood acute lymphoblastic leukaemia and polymorphisms within the tumour necrosis factor and the interleukin-10 genes. Leukemia 16: 1437.

Lee E.Y., Parry G., and Bissell M.J. 1984. Modulation of secreted proteins of mouse mammary epithelial cells by the collagenous substrata. J. Cell Biol. 98: 146.

Lee E.Y., Lee W.H., Kaetzel C.S., Parry G., and Bissell M.J. 1985. Interaction of mouse mammary epithelial cells with collagen substrata: Regulation of casein gene expression and secretion. Proc. Natl. Acad. Sci. 82: 1419.

Lin C.Q. and Bissell M.J. 1993. Multi-faceted regulation of cell differentiation by extracellular matrix. FASEB J. 7: 737.

List K., Szabo R., Molinolo A., Sriuranpong V., Redeye V., Murdock T., Burke B., Nielsen B.S., Gutkind J.S., and Bugge T.H. 2005. Deregulated matriptase causes ras-independent multistage carcinogenesis and promotes ras-mediated malignant transformation. Genes Dev. 19: 1934.

Liu H., Radisky D.C., Wang F., and Bissell M.J. 2004. Polarity and proliferation are controlled by distinct signaling pathways downstream of PI3-kinase in breast epithelial tumor cells. $J$. Cell Biol. 164: 603.

Lochter A., Galosy S., Muschler J., Freedman N., Werb Z., and Bissell M.J. 1997a. Matrix metalloproteinase stromelysin-1 triggers a cascade of molecular alterations that leads to stable epithelial-to-mesenchymal conversion and a premalignant phenotype in mammary epithelial cells. J. Cell Biol. 139: 1861.

Lochter A., Srebrow A., Sympson C.J., Terracio N., Werb Z., and Bissell M.J. 1997b. Misregulation of stromelysin-1 expression in mouse mammary tumor cells accompanies acquisition of stromelysin-1-dependent invasive properties. J. Biol. Chem. 272: 5007.

Loktionov A. 2004. Common gene polymorphisms, cancer progression and prognosis. Cancer Lett. 208: 1.

Martin G.S. 2004. The road to Src. Oncogene 23: 7910.

Martinez-Escribano J.A., Moya-Quiles M.R., Muro M., MontesAres O., Hernandez-Caselles T., Frias J.F., and AlvarezLopez M.R. 2002. Interleukin-10, interleukin-6 and interferon-gamma gene polymorphisms in melanoma patients. Melanoma Res. 12: 465.

Matos P., Collard J.G., and Jordan P. 2003. Tumor-related alternatively spliced Rac1b is not regulated by Rho-GDP dissociation inhibitors and exhibits selective downstream signaling. J. Biol. Chem. 278: 50442.

McCarron S.L., Edwards S., Evans P.R., Gibbs R., Dearnaley D.P., Dowe A., Southgate C., Easton D.F., Eeles R.A., and Howell W.M. 2002. Influence of cytokine gene polymorphisms on the development of prostate cancer. Cancer Res. 62: 3369

McCarthy R.P., Zhang S., Bostwick D.G., Qian J., Eble J.N., Wang M., Lin H., and Cheng L. 2004. Molecular genetic evidence for different clonal origins of epithelial and stromal components of phyllodes tumor of the prostate. Am. J. Pathol. 165: 1395.

Mestiri S., Bouaouina N., Ahmed S.B., Khedhaier A., Jrad B.B., Remadi S., and Chouchane L. 2001. Genetic variation in the tumor necrosis factor-alpha promoter region and in the stress protein hsp70-2: Susceptibility and prognostic implications in breast carcinoma. Cancer 91: 672 .

Michalopoulos G. and Pitot H.C. 1975. Primary culture of parenchymal liver cells on collagen membranes. Morphological and biochemical observations. Exp. Cell Res. 94: 70.

Mintz B. and Illmensee K. 1975. Normal genetically mosaic mice produced from malignant teratocarcinoma cells. Proc. 
Natl. Acad. Sci. 72: 3585.

Moinfar F., Man Y.G., Arnould L., Bratthauer G.L., Ratschek M., and Tavassoli F.A. 2000. Concurrent and independent genetic alterations in the stromal and epithelial cells of mammary carcinoma: Implications for tumorigenesis. Cancer Res. 60: 2562 .

Montie J.E., Wood D.P., Jr., Pontes J.E., Boyett J.M., and Levin H.S. 1989. Adenocarcinoma of the prostate in cystoprostatectomy specimens removed for bladder cancer. Cancer 63: 381 .

Moon R.T., Bowerman B., Boutros M., and Perrimon N. 2002. The promise and perils of Wnt signaling through beta-catenin. Science 296: 1644

Muschler J., Lochter A., Roskelley C.D., Yurchenco P., and Bissell M.J. 1999. Division of labor among the $\alpha 6 \beta 4$ integrin, $\beta 1$ integrins, and an E3 laminin receptor to signal morphogenesis and beta-casein expression in mammary epithelial cells. Mol. Biol. Cell 10: 2817.

Myers C.A., Schmidhauser C., Mellentin-Michelotti J., Fragoso G., Roskelley C.D., Casperson G., Mossi R., Pujuguet P., Hager G., and Bissell M.J. 1998. Characterization of BCE-1, a transcriptional enhancer regulated by prolactin and extracellular matrix and modulated by the state of histone acetylation. Mol. Cell. Biol. 18: 2184.

Nielsen M., Thomsen J.L., Primdahl S., Dyreborg U., and Andersen J.A. 1987. Breast cancer and atypia among young and middle-aged women: A study of 110 medicolegal autopsies. Br. J. Cancer 56: 814.

Nieto M.A. 2002. The snail superfamily of zinc-finger transcription factors. Nat. Rev. Mol. Cell Biol. 3: 155 .

Nishioka Y., Sagae S., Nishikawa A., Ishioka S., and Kudo R. 2003. A relationship between Matrix metalloproteinase-1 (MMP-1) promoter polymorphism and cervical cancer progression. Cancer Lett. 200: 49.

Olumi A.F., Grossfeld G.D., Hayward S.W., Carroll P.R., Tlsty T.D., and Cunha G.R. 1999. Carcinoma-associated fibroblasts direct tumor progression of initiated human prostatic epithelium. Cancer Res. 59: 5002.

Paget S. 1889. The distribution of secondary growths in cancer of the breast. Lancet 1: 571

Parmar H. and Cunha G.R. 2004. Epithelial-stromal interactions in the mouse and human mammary gland in vivo. Endocr. Relat. Cancer 11: 437.

Pasca di Magliano M. and Hebrok M. 2003. Hedgehog signalling in cancer formation and maintenance. Nat. Rev. Cancer 3: 903.

Paterson R.F., Ulbright T.M., MacLennan G.T., Zhang S., Pan C.X., Sweeney C.J., Moore C.R., Foster R.S., Koch M.O., Eble J.N., and Cheng L. 2003. Molecular genetic alterations in the laser-capture-microdissected stroma adjacent to bladder carcinoma. Cancer 98: 1830.

Peebles F. 1911. On the interchange of limbs of the chick by transplantation. Biol. Bull. 20: 14.

Petersen O.W., Ronnov-Jessen L., Howlett A.R., and Bissell M.J. 1992. Interaction with basement membrane serves to rapidly distinguish growth and differentiation pattern of normal and malignant human breast epithelial cells. Proc. Natl. Acad. Sci. 89: 9064.

Pharoah P.D., Dunning A.M., Ponder B.A., and Easton D.F. 2004. Association studies for finding cancer-susceptibility genetic variants. Nat. Rev. Cancer 4: 850 .

Pollard J.W. 2004. Tumour-educated macrophages promote tumour progression and metastasis. Nat. Rev. Cancer 4: 71.

Puri P.L., Bhakta K., Wood L.D., Costanzo A., Zhu J., and Wang J.Y. 2002. A myogenic differentiation checkpoint activated by genotoxic stress. Nat. Genet. 32: 585 .

Radisky D.C. and Bissell M.J. 2004. Cancer. Respect thy neighbor! Science 303: 775.

Radisky D.C., Levy D.D., Littlepage L.E., Liu H., Nelson C.M., Fata J.E., Leake D., Godden E.L., Albertson D.G., Nieto M.A., Werb Z., and Bissell M.J. 2005. Rac1b and reactive oxygen species mediate MMP-3-induced EMT and genomic instability. Nature 436: 123.

Radtke F. and Raj K. 2003. The role of Notch in tumorigenesis: Oncogene or tumour suppressor? Nat. Rev. Cancer 3: 756.
Risch N.J. 2000. Searching for genetic determinants in the new millennium. Nature 405: 847.

Roberts D.J. 2000. Molecular mechanisms of development of the gastrointestinal tract. Dev. Dyn. 219: 109.

Robinson S.C. and Coussens L.M. 2005. Soluble mediators of inflammation during tumor development. Adv. Cancer Res. 93: 159.

Ronnov-Jessen L., Petersen O.W., and Bissell M.J. 1996. Cellular changes involved in conversion of normal to malignant breast: Importance of the stromal reaction. Physiol. Rev. 76: 69.

Roskelley C.D., Srebrow A., and Bissell M.J. 1995. A hierarchy of ECM-mediated signalling regulates tissue-specific gene expression. Curr. Opin. Cell Biol. 7: 736.

Sakakura T., Nishizuka Y., and Dawe C.J. 1976. Mesenchymedependent morphogenesis and epithelium-specific cytodifferentiation in mouse mammary gland. Science 194: 1439.

Schmeichel K.L. and Bissell M.J. 2003. Modeling tissue-specific signaling and organ function in three dimensions. J. Cell Sci. 116: 2377.

Schmidhauser C., Casperson G.F., Myers C.A., Sanzo K.T., Bolten S., and Bissell M.J. 1992. A novel transcriptional enhancer is involved in the prolactin- and extracellular matrixdependent regulation of beta-casein gene expression. Mol. Biol. Cell 3: 699.

Schor S.L., Ellis I.R., Jones S.J., Baillie R., Seneviratne K., Clausen J., Motegi K., Vojtesek B., Kankova K., Furrie E., Sales M.J., Schor A.M., and Kay R.A. 2003. Migration-stimulating factor: A genetically truncated onco-fetal fibronectin isoform expressed by carcinoma and tumor-associated stromal cells. Cancer Res. 63: 8827.

Shah M., Foreman D.M., and Ferguson M.W. 1995. Neutralisation of TGF-beta 1 and TGF-beta 2 or exogenous addition of TGF-beta 3 to cutaneous rat wounds reduces scarring. J. Cell Sci. 108: 985.

Shimura T., Hagihara M., Takebe K., Munkhbat B., Ogoshi K., Mitomi T., Nagamachi Y., and Tsuji K. 1995. 10.5-kb homozygote of tumor necrosis factor-beta gene is associated with a better prognosis in gastric cancer patients. Cancer (suppl. 6) 75: 1450 .

Sieweke M.H. and Bissell M.J. 1994. The tumor-promoting effect of wounding: A possible role for TGF-beta-induced stromal alterations. Crit. Rev. Oncog. 5: 297.

Sieweke M.H., Thompson N.L., Sporn M.B., and Bissell M.J. 1990. Mediation of wound-related Rous sarcoma virus tumorigenesis by TGF-beta. Science 248: 1656.

Spemann H. 1918. Uber die Determination der ersten Organanlagan des Amphibienembryo. Wilhelm Roux Arch. Entwichlungsmech. Org. 43: 448.

Spemann H. and Mangold H. 1924. Induction of embryonic primordia by implantation of organizers from a different species. In Foundations of experimental embryology (ed. B.H. Willier and J.M. Oppenheimer), p. 144. Hafner, New York.

Sternlicht M.D. and Werb Z. 2001. How matrix metalloproteinases regulate cell behavior. Annu. Rev. Cell Dev. Biol. 17: 463.

Sternlicht M.D., Lochter A., Sympson C.J., Huey B., Rougier J.P., Gray J.W., Pinkel D., Bissell M.J., and Werb Z. 1999. The stromal proteinase MMP3/stromelysin-1 promotes mammary carcinogenesis. Cell 98: 137.

Stoker A.W., Hatier C., and Bissell M.J. 1990a. The embryonic environment strongly attenuates $\mathrm{v}$-src oncogenesis in mesenchymal and epithelial tissues, but not in endothelia. J. Cell Biol. 111: 217.

Stoker A.W., Streuli C.H., Martins-Green M., and Bissell M.J. 1990b. Designer microenvironments for the analysis of cell and tissue function. Curr. Opin. Cell Biol. 2: 864.

Streuli C.H., Bailey N., and Bissell M.J. 1991. Control of mammary epithelial differentiation: Basement membrane induces tissue-specific gene expression in the absence of cell-cell interaction and morphological polarity. J. Cell Biol. 115: 1383.

Streuli C.H., Schmidhauser C., Kobrin M., Bissell M.J., and Derynck R. 1993. Extracellular matrix regulates expression of the TGF-beta 1 gene. J. Cell Biol. 120: 253. 
Streuli C.H., Schmidhauser C., Bailey N., Yurchenco P., Skubitz A.P., Roskelley C., and Bissell M.J. 1995. Laminin mediates tissue-specific gene expression in mammary epithelia. $J$. Cell Biol. 129: 591.

Sympson C.J., Talhouk R.S., Alexander C.M., Chin J.R., Clift S.M., Bissell M.J., and Werb Z. 1994. Targeted expression of stromelysin-1 in mammary gland provides evidence for a role of proteinases in branching morphogenesis and the requirement for an intact basement membrane for tissue-specific gene expression. J. Cell Biol. 125: 681.

Thiery J.P. 2002. Epithelial-mesenchymal transitions in tumour progression. Nat. Rev. Cancer 2: 442.

Tuhkanen H., Anttila M., Kosma V.M., Yla-Herttuala S., Heinonen S., Kuronen A., Juhola M., Tammi R., Tammi M., and Mannermaa A. 2004. Genetic alterations in the peritumoral stromal cells of malignant and borderline epithelial ovarian tumors as indicated by allelic imbalance on chromosome 3p. Int. J. Cancer 109: 247.

Virchow R. 1863. Aetologie der neoplastichen Geschwulste/ Pathogenie der neoplastischen Geschwulste. In Die Krankenhaften Geschwulste, p. 58. Verlag von August Hirchwald, Berlin, Germany.

Wahl G.M., Padgett R.A., and Stark G.R. 1979. Gene amplification causes overproduction of the first three enzymes of UMP synthesis in N-(phosphonacetyl)-L-aspartate-resistant hamster cells. J. Biol. Chem. 254: 8679.

Waite K.A. and Eng C. 2003. From developmental disorder to heritable cancer: It's all in the BMP/TGF-beta family. Nat. Rev. Genet. 4: 763.

Wang F., Weaver V.M., Petersen O.W., Larabell C.A., Dedhar S., Briand P., Lupu R., and Bissell M.J. 1998. Reciprocal interactions between $\beta 1$-integrin and epidermal growth factor receptor in three-dimensional basement membrane breast cultures: A different perspective in epithelial biology. Proc. Natl. Acad. Sci. 95: 14821.
Warzocha K., Ribeiro P., Bienvenu J., Roy P., Charlot C., Rigal D., Coiffier B., and Salles G. 1998. Genetic polymorphisms in the tumor necrosis factor locus influence non-Hodgkin's lymphoma outcome. Blood 91: 3574.

Weaver V.M., Petersen O.W., Wang F., Larabell C.A., Briand P., Damsky C., and Bissell M.J. 1997. Reversion of the malignant phenotype of human breast cells in three-dimensional culture and in vivo by integrin blocking antibodies. J. Cell Biol. 137: 231.

Weaver V.M., Lelievre S., Lakins J.N., Chrenek M.A., Jones J.C., Giancotti F., Werb Z., and Bissell M.J. 2002. $\beta 4$ Integrin-dependent formation of polarized three-dimensional architecture confers resistance to apoptosis in normal and malignant mammary epithelium. Cancer Cell 2: 205.

Weber F., Fukino K., Sawada T., Williams N., Sweet K., Brena R.M., Plass C., Caldes T., Mutter G.L., Villalona-Calero M.A., and Eng C. 2005. Variability in organ-specific EGFR mutational spectra in tumour epithelium and stroma may be the biological basis for differential responses to tyrosine kinase inhibitors. Br. J. Cancer 92: 1922.

Werner E. and Werb Z. 2002. Integrins engage mitochondrial function for signal transduction by a mechanism dependent on Rho GTPases. J. Cell Biol. 158: 357.

Wernert N., Locherbach C., Wellmann A., Behrens P., and Hugel A. 2001. Presence of genetic alterations in microdissected stroma of human colon and breast cancers. Anticancer Res. 21: 2259.

Ye S., Dhillon S., Turner S.J., Bateman A.C., Theaker J.M., Pickering R.M., Day I., and Howell W.M. 2001. Invasiveness of cutaneous malignant melanoma is influenced by matrix metalloproteinase 1 gene polymorphism. Cancer Res. 61: 1296.

Yu J., McMahon A.P., and Valerius M.T. 2004. Recent genetic studies of mouse kidney development. Curr. Opin. Genet. Dev. 14: 550. 


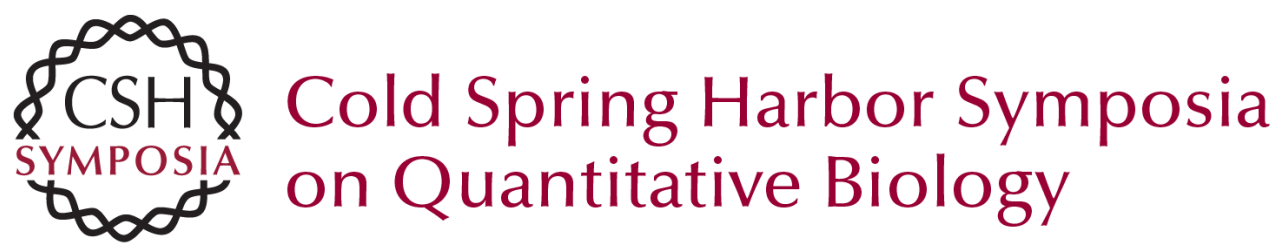

\section{Microenvironmental Regulators of Tissue Structure and Function Also Regulate Tumor Induction and Progression: The Role of Extracellular Matrix and Its Degrading Enzymes}

M.J. BISSELL, P.A. KENNY and D.C. RADISKY

Cold Spring Harb Symp Quant Biol 2005 70: 343-356

Access the most recent version at doi:10.1101/sqb.2005.70.013

References This article cites 129 articles, 60 of which can be accessed free at: http://symposium.cshlp.org/content/70/343.full.html\#ref-list-1

License

Email Alerting Receive free email alerts when new articles cite this article - sign up in Service the box at the top right corner of the article or click here. 